\title{
ERRATUM
}

\section{The historical and current status of Pink-headed Duck Rhodonessa caryophyllacea in Myanmar - Erratum}

Andrew W. Tordoff, Tim Appleton, Jonathan C. Eames, Karin Eberhardt, Htin Hla, Khin Ma Ma Thwin, Sao Myo Zaw, Saw Moses and Sein Myo Aung

doi: $10.1017 /$ So959270908000063

Volume 18 (2008) Number 1

Pages $38-52$

Following is a corrected version of the article that originally appeared in BCI Volume 18, Number 1 , pages $38-52$. Owing to a publisher's error, the illustrations in the article did not appear in colour in the original printing and are shown here as they should have appeared. Note that the text is the same as in the original printing and is only reprinted here for the reader's convenience. Citations to this article should use the original volume, issue and page numbers. 


\title{
The historical and current status of Pink-headed Duck Rhodonessa caryophyllacea in Myanmar
}

\author{
ANDREW W. TORDOFF, TIM APPLETON, JONATHAN C. EAMES, KARIN \\ EBERHARDT, HTIN HLA, KHIN MA MA THWIN, SAO MYO ZAW, SAW MOSES \\ and SEIN MYO AUNG
}

\section{Summary}

Pink-headed Duck Rhodonessa caryophyllacea is a Critically Endangered species that has not been confirmed in the wild since 1948-1949. Historical records of the species are concentrated in India, although there are also a few from Myanmar. Between 2003 and 2005, BirdLife International and the Biodiversity and Nature Conservation Association (BANCA) conducted a series of field surveys of wetland habitats in the lowlands of Kachin state, an area with a cluster of historical records of the species. These were the first targeted efforts to assess the status of the species in Myanmar. These surveys were complemented by reviews of museum specimens and literature relating to the species in Myanmar. Two specimen records represent very strong evidence that the species occurred in Myanmar historically, although they shed little light on its seasonal status in the country. The surveys conducted by BirdLife International and BANCA were unable to confirm the continued occurrence of Pink-headed Duck in Myanmar. However, they did generate a limited amount of equivocal direct evidence, most notably two possible but unconfirmed sightings. There are several reasons for believing that the species may still persist in the lowlands of Kachin state and, perhaps, elsewhere in Myanmar. Shyness, combined with rarity, possible nocturnal habits and the impenetrability of its habitats, means that the species tended to be under-recorded historically, and may continue to be so currently. Further surveys are required to confirm this.

\section{Introduction}

In its review of globally threatened bird species in Asia, Saving Asia's Threatened Birds, BirdLife International (2003) presents a table of "Asia's lost species: Critical and Endangered bird species not recorded in recent decades". The II species in this table include Pink-headed Duck Rhodonessa caryophyllacea, a Critically Endangered species (IUCN 2006), which has no captive population and has not been confirmed in the wild since 1948-1949 (Singh 1967, BirdLife International 2001).

Historical records of Pink-headed Duck are concentrated in India, with a much smaller number from Myanmar, and a handful from Bangladesh and Nepal (BirdLife International 2001). Within India, records are concentrated in the north and north-east of the country, with much smaller numbers from the Punjab and southern India. This distribution of records may indicate that the species was previously more widespread and common throughout India but was already undergoing a decline prior to the arrival of European collectors, that it bred in northern and north-eastern India and occurred outside these areas as a non-breeding visitor, or a combination of these factors.

Whether or not Pink-headed Duck was already declining before it was described for science, it appears to have undergone a rapid decline during the nineteenth and first half of the twentieth centuries, as a result of habitat loss, perhaps compounded by hunting pressure. A major factor in 
the decline and possible extinction of the species in South Asia was the phenomenal growth and expansion of the human population in its range over this period, and the accompanying massive conversion of lowland wetlands to cultivation (Bucknill 1924, Ali 1960, BirdLife International 2001). Based on a comprehensive review of information on the status of the species, BirdLife International (2001) concluded that the "duck is probably extinct, but until the last known areas of its former range are surveyed, this cannot be confirmed".

One area of its former range that had, until the late 1990s, received little recent ornithological survey effort is Myanmar (Burma). The few historical records of Pink-headed Duck from the country are concentrated in the lowlands of Kachin state and Mandalay division (Figures 1 and 2).

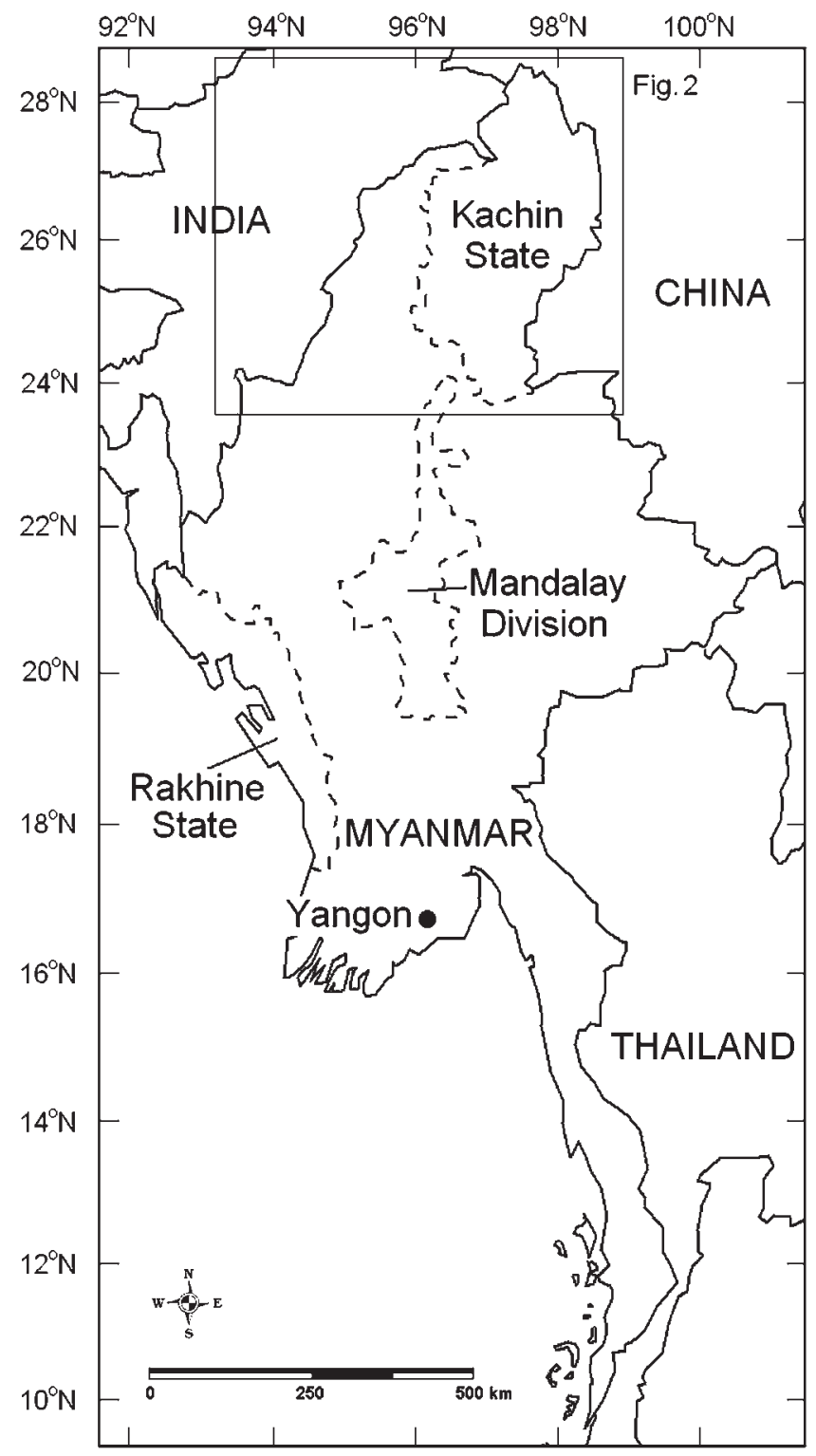

Figure 1. Map of Myanmar, showing selected localities mentioned in the text. 


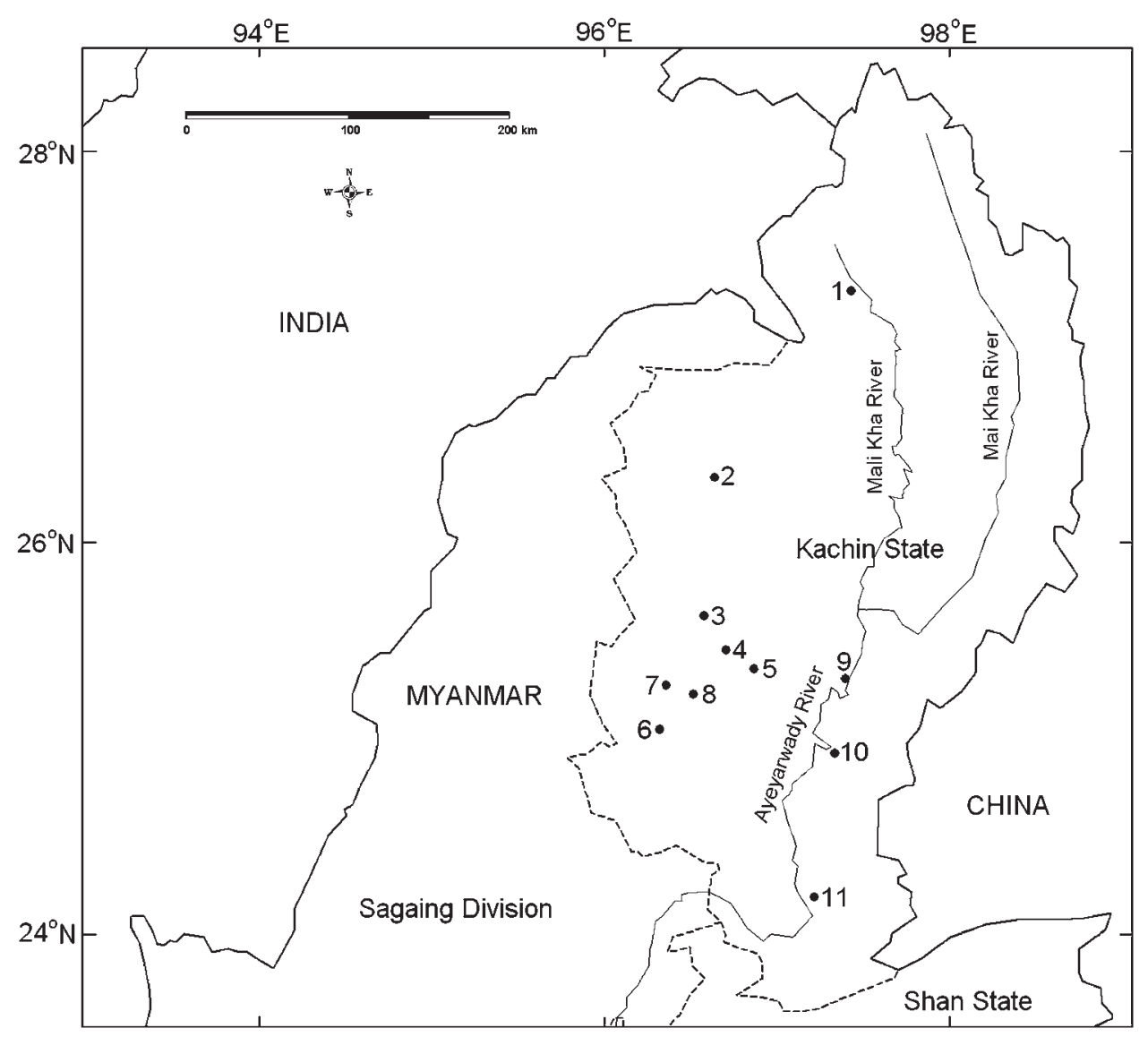

Figure 2. Map of Kachin State, Myanmar, showing selected localities mentioned in the text. 1 , Machanbaw; 2, Tanai river; 3, Nat Kaung river; 4, Kamaing town; 5, Mogaung Chaung; 6, Indawgyi lake; 7, Nawng Kwin; 8, Indawgyi river; 9, Myitkyina; 10, Talawgyi; 11, Bhamo.

Prior to 2003, however, there had been no specific attempt to assess the current status of the species in these areas, although they were visited during several general waterbird surveys (van der Ven 2000, 2001, 2002, 2003, Davies et al. 2004). In this context, BirdLife International and the Biodiversity and Nature Conservation Association (BANCA) conducted a series of field surveys between 2003 and 2005, focusing on wetland habitats in the lowlands of Kachin state, paying particular attention to assessing the current status of Pink-headed Duck (Tordoff et al. in press).

The first BirdLife/BANCA survey, which took place between 11 and 17 April 2003, focused on the Ayeyarwady (Irrawaddy) river between Myitkyina and Bhamo towns, and nearby nonflowing wetlands. The second survey, between 11 and 26 November 2003, focused on the Tanai river and associated ox-bow lakes. The third survey, between 28 November and 15 December 2004, revisited the Tanai river and associated ox-bows, and also included Indawgyi lake and river and the nearby Nawng Kwin wetland. The fourth survey, from 1o October to 3 November 2005, concentrated on the Kamaing area, the Mogaung Chaung (Mogaung river) and the Warazup area of Hukaung Tiger Reserve.

At each site visited, satellite images (of various sources and dates) were used to identify potentially suitable habitats for Pink-headed Duck, where survey effort was then concentrated. Particular attention was given to surveying ox-bows associated with lowland rivers, and natural 
grasslands containing pools. At each site visited, birds seen and heard were recorded by between two and seven observers, and local people were interviewed.

Before the 2005 survey, colour posters and flyers were distributed throughout the lowlands of Kachin state, offering a cash reward to any person who was able to show a live Pink-headed Duck to the survey team. The posters displayed colour pictures of Pink-headed Duck and two possible confusion species: Ruddy Shelduck Tadorna ferruginea and Red-crested Pochard Rhodonessa rufina.

In addition to conducting field surveys, the authors carried out a thorough review of specimens and literature relating to Pink-headed Duck in Myanmar. Based on these studies, this paper reviews historical and recent records of Pink-headed Duck from Myanmar, and evaluates the historical and current status of the species in the country.

\section{Historical status in Myanmar}

Six historical (pre-1950) records and one fairly recent (1950-1979) record of Pink-headed Duck in Myanmar are listed by BirdLife International (2001). Each record is discussed below.

\section{Bhamo}

Pink-headed Duck is described as occurring at Bhamo (in present-day Kachin state) by Blyth (1875), but no further details are given. This record is repeated by a number of authors, including Oates (1883) and Smythies (1986). It may also be the source of the comment in Oates and Blandford (1889-1898) that Pink-headed Duck "has been recorded from north of Bhámo, but nowhere else in the Irrawaddy valley". The Bhamo area was the focus of a moderate amount of ornithological survey effort in the early part of the twentieth century, most notably by Harington (1909-1910), but no further records of the species were made. There are a large number of ox-bows near to Bhamo town ( $24^{\circ} 15^{\prime} 15^{\prime \prime} \mathrm{N}, 97^{\circ} 13^{\prime} 30^{\prime \prime} \mathrm{E}$; $110 \mathrm{~m}$ a.s.l.; Figure 2). While these ox-bows currently show signs of significant human disturbance, they could have supported the species historically, when levels of human disturbance were presumably far lower than at present.

\section{Arakan}

Blyth (1875) also describes Pink-headed Duck as occurring in Arakan (present-day Rakhine state; Figure I), but no further details are given. This record is repeated by a number of authors, including Oates (1883) and Smythies (1986). Present-day Rakhine state was the focus of only modest historical survey effort (e.g. Christison et al. 1946) and has received almost no recent ornithological study. In this context, the absence of subsequent records from the area should not necessarily be interpreted as indicating that the species no longer occurs (or never occurred) there.

\section{Myitkyina}

Harington (1909) includes the species in a table of the "Distribution of Birds in Burma" with the note "Myitkyina, rare in Burma". No further details are given. Myitkyina town $\left(25^{\circ} 23^{\prime} \mathrm{oo}^{\prime} \mathrm{N}\right.$, $97^{\circ} 24^{\prime} \mathrm{OO}^{\prime \prime} \mathrm{E}$; $145 \mathrm{~m}$ a.s.l.; Figure 2) lies on the Ayeyarwady river, $125 \mathrm{~km}$ north of Bhamo. Pinkheaded Duck appears never to have utilized rivers, although it did occur in areas flooded by them (BirdLife International 2001).

\section{Koolay}

On 25 December 1908, Jardine (1909) shot a female Pink-headed Duck at Koolay, near Singu, in present-day Mandalay division. The skin is in the collection of the Bombay Natural History 
Society (BNHS) (Figure 3). The location on the specimen label is given as "Singu, Koolay, Upper Burma", while the date is given as 27 January 1909. The discrepancy between the date of collection given by Jardine (1909) and the date on the specimen label may be due to the latter date being when the specimen was entered into the collection of BNHS. The locality "Koolay" may correspond to the present-day village of Kule $\left(22^{\circ} 34^{\prime} 45^{\prime \prime} \mathrm{N}, 95^{\circ} 5^{\prime} 45^{\prime \prime} \mathrm{E}\right.$; $60 \mathrm{~m}$ a.s.l.), which lies $3 \mathrm{~km}$ north of Singu town on the shore of Khu Le In, a medium-sized (c. 200 ha) lake near the Ayeyarwady river.

\section{Mandalay bazaar}

The second specimen from Myanmar is a male acquired from Mandalay bazaar in February 1910 and held at the American Museum of Natural History (AMNH) (Figure 4). The label of this specimen bears the following information: "O", Mandalay bazaar, 10.02.10, H. H. Harington". This represents the last confirmed record of the species from Myanmar. Mandalay $\left(21^{\circ} 58^{\prime} 30^{\prime \prime} \mathrm{N}\right.$, $96^{\circ} 5^{\prime} \mathrm{Oo}^{\prime \prime} \mathrm{E} ; 80 \mathrm{~m}$ a.s.l.) is c. $60 \mathrm{~km}$ south of Singu town.

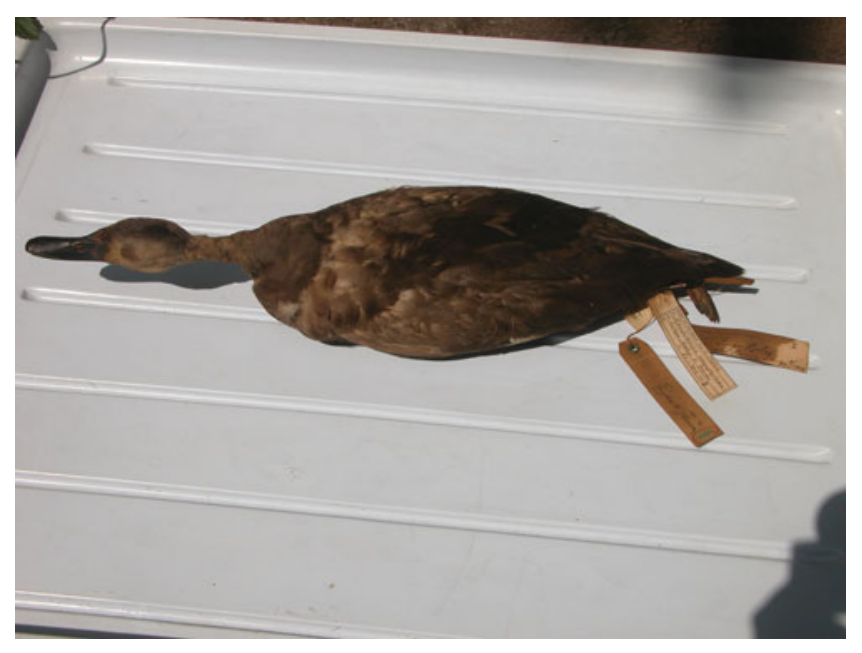

Figure 3. Skin of a female Pink-headed Duck in the collection of BNHS. The specimen was collected at Koolay, near Singu, in present-day Mandalay division, on 25 December 1908. (Photograph courtesy of BNHS.)

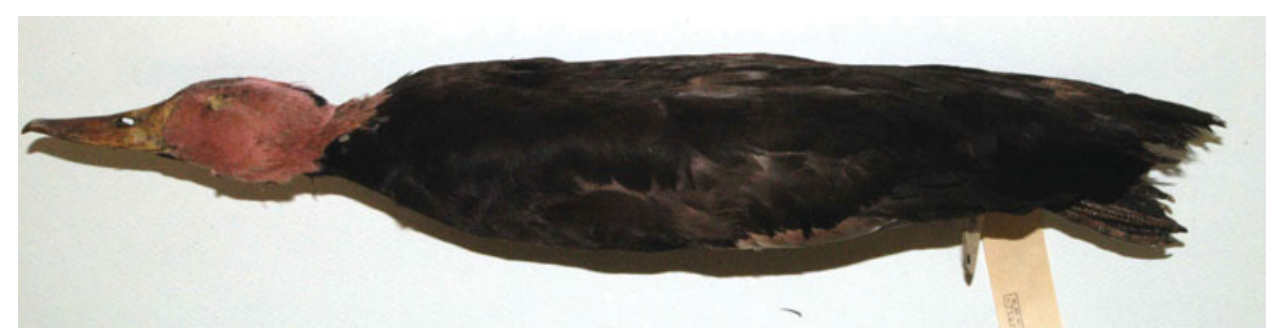

Figure 4. Skin of a male Pink-headed Duck in the collection of AMNH. The specimen was collected acquired from Mandalay bazaar on 10 February 1910. (Photograph courtesy of AMNH.) 


\section{Mandalay}

In his note on the occurrence of Pink-headed Duck in Myanmar, Jardine (1909) comments that "Oates mentions 4 of these duck as being shot near Mandalay", without giving a date. It is notable that this report is from the same general area as the two specimen records.

\section{Mali Kha}

Kear and Williams (1978) passed on a report by U Tun Yin of five birds in rapids on the Mali Kha river (a tributary of the Ayeyarwady river), near Machanbaw, Kachin state (Figure 2), in 1965-1966. A letter from U Tun Yin to W. King of the International Council for Bird Preservation, dated 2 November 1979, reveals that original source of this report was Saw Cushing Po, a local government official in Putao district, Kachin state. According to this letter, Saw Cushing Po "was out shooting ... in the winter of 1967-1968" when he "saw a small flock of some 4-6 Pink-headed Ducks in the rapids of Mali Kha". The letter goes on to state that Saw Cushing Po "continued to receive reports of the sighting of small flocks of Pink-headed Duck from trustworthy friends", although "the Pink-headed Duck do not, however, breed in the Putao district". The letter is accompanied by a map, which shows the location where the purported sighting of Pink-headed Duck was made. The location of the reported sighting $\left(27^{\circ} 19^{\prime} \mathrm{Oo}^{\prime \prime} \mathrm{N}, 97^{\circ} 34^{\prime} 45^{\prime \prime} \mathrm{E}, \mathrm{c} .600 \mathrm{~m}\right.$ a.s.l.) appears, from remote sensing data, to lie along a lowgradient section of the Mali Kha, approximately $150 \mathrm{~m}$ wide, with a few large sandbars. This record fails to conform with almost all evidence to date that the species was restricted to lowlands and never used rivers (BirdLife International 2001), and should be treated as provisional.

\section{Seasonal status}

The specimen records from Koolay and Mandalay bazaar represent very strong evidence that Pink-headed Duck occurred in Myanmar historically. However, there remains uncertainty about the species' seasonal status, as it is possible that it was a winter visitor to Myanmar not a resident. The historical records from Myanmar shed little light on its seasonal status, because only three of them are dated. Besides, although the specimen acquired from Mandalay bazaar is dated as February, it is not known when the bird was originally hunted (or captured). Moreover, although the anecdotal report from along the Mali Kha is dated as winter 1967-1968, there are strong reasons to doubt that this report refers to Pink-headed Duck. Consequently, the only reliable information on seasonal status in Myanmar is the specimen shot by Jardine (1909) on 25 December 1908. This record is consistent with both the species being a winter visitor to Myanmar and it being a resident.

\section{Current status in Myanmar}

BirdLife International (2001) presents a single recent (1980-2001) anecdotal report of Pinkheaded Duck from Myanmar. The BirdLife/BANCA surveys were unable to confirm the continued occurrence of Pink-headed Duck in Myanmar, although they did generate several first-hand anecdotal reports and two unconfirmed sightings. Each record is discussed below.

\section{Talawgyi}

BirdLife International (2001) cites an observation by U Tun Yin (per U Nay Myo Shwe per S. Chan) of two birds resembling illustrations of Pink-headed Duck and never previously seen by the observer. The birds were seen near Talawgyi village $\left(25^{\circ} 04^{\prime} 30^{\prime \prime} \mathrm{N}, 97^{\circ} 18^{\prime} 30^{\prime \prime} \mathrm{E}\right.$, I $140 \mathrm{~m}$ a.s.l.; Figure 2), not far from Myitkyina, in winter 1998/1999. During the preparation of this paper, U 
Nay Myo Shwe informed the authors that he had never met anyone at Talawgyi who had reported the species and that in fact he had never conducted interviews for the species there. Consequently, the report in BirdLife International (2001) should be treated as erroneous.

During the BirdLife/BANCA surveys in April 2003 and October-November 2005, an anecdotal report of Pink-headed Duck near Talawgyi was received from an ex-hunter, Dr La Kha. He reported that, in 1993, he visited a small lake, about $200 \mathrm{~m}$ wide, on the east bank of the Ayeyarwady river, a short distance downstream of Talawgyi. He claimed to have seen three Pink-headed Ducks on this lake but to have left them undisturbed, not having had his gun with him at the time. He added that this lake is now drained every February to catch fish, so he did not expect that it would still be suitable for Pink-headed Duck.

Talawgyi village lies alongside the Ayeyarwady river, c. $65 \mathrm{~km}$ downstream of Myitkyina town. Within a $10 \mathrm{~km}$ radius of Talawgyi village, there are over 30 ox-bows, formed by the Ayeyarwady and its tributaries. The moderately high levels of human disturbance observed in April 2003 suggest that the area may now be less suitable for the species than certain other sites visited during the BirdLife/BANCA surveys.

\section{Tanai River}

On 22 November 2003, Pasi Naw Aung, a hunter from Tanai town, reported that, more than three years previously, he saw four Pink-headed Ducks on Se Hnaung In $\left(26^{\circ} 24^{\prime} 45^{\prime \prime} \mathrm{N}\right.$, $\left.96^{\circ} 3 I^{\prime} 45^{\prime \prime} \mathrm{E}\right)$, one of which he killed at night. He added that the habitat of the species is grass and shallow water near trees. Later the same day, Win Bo, a fisherman, reported to the survey team that he saw a single Pink-headed Duck on Se Hnaung in September or October 2003. He added that he saw the bird just after dawn, both on the water and in flight.

Se Hnaung In lies along the Tanai river (Figure 2), a tributary of the Chindwin river, which flows through Hukaung Tiger Reserve. The meandering Tanai river has generated a large number of ox-bows, some of which support large expanses of emergent and/or floating vegetation, while others have predominantly open water. A total of 13 ox-bows were visited during the BirdLife/BANCA surveys in November 2003 and November-December 2004. Of these ox-bows, Se Hnaung In appeared to be particularly suitable for Pink-headed Duck, with a large belt of emergent reeds along the northern side and an extensive area (c. 10 ha) at the western end. Unfortunately, the reeds could not be penetrated by boat, and vantage points along the shore of the ox-bow only permitted views of open water. Consequently, it was not possible to determine whether the reeds contained small pools that might have been suitable for Pinkheaded Duck.

\section{Nawng Kwin}

Between $I$ and 5 December 2004, the survey team visited Nawng Kwin $\left(25^{\circ} 20^{\prime} 30^{\prime \prime} \mathrm{N}, 96^{\circ} 22^{\prime} \mathrm{oo}^{\prime \prime} \mathrm{E}\right.$; c. $200 \mathrm{~m}$ a.s.l.; Figure 2), a medium-sized (c. 1,500 ha) wetland to the north of Indawgyi lake (Figure 2). Nawng Kwin is a seasonally inundated grassland, with some swamp forest and a few scattered, open pools, up to $200 \mathrm{~m}$ in diameter (Figure 5). On I December, a young man, Saw Aung, who reported knowing Pink-headed Duck, was asked to flush birds from pools in the grassland. At 11h15, he flushed a flock of around 45 Mallard Anas platyrhnchos. A single bird broke off from the flock, climbed quite high, circled for 2 to 3 minutes, and then descended into the grassland. For most of the time, the bird was at a distance of $300-500 \mathrm{~m}$ from the observers, although it was over I $\mathrm{km}$ away by the time it landed.

Three observers (T.A., J.C.E. and A.W.T.) watched the bird through telescopes for most of the time that it was airborne. All three noted that the bird was medium-sized (around the same size as a Mallard), with a pale head and neck, contrasting with a dark body and upperwings. Only two medium-sized ducks occurring in South-East Asia have this combination of features: Pinkheaded Duck, and Spot-billed Duck Anas poecilorhyncha. The lack of white tertials rules out $A$. 


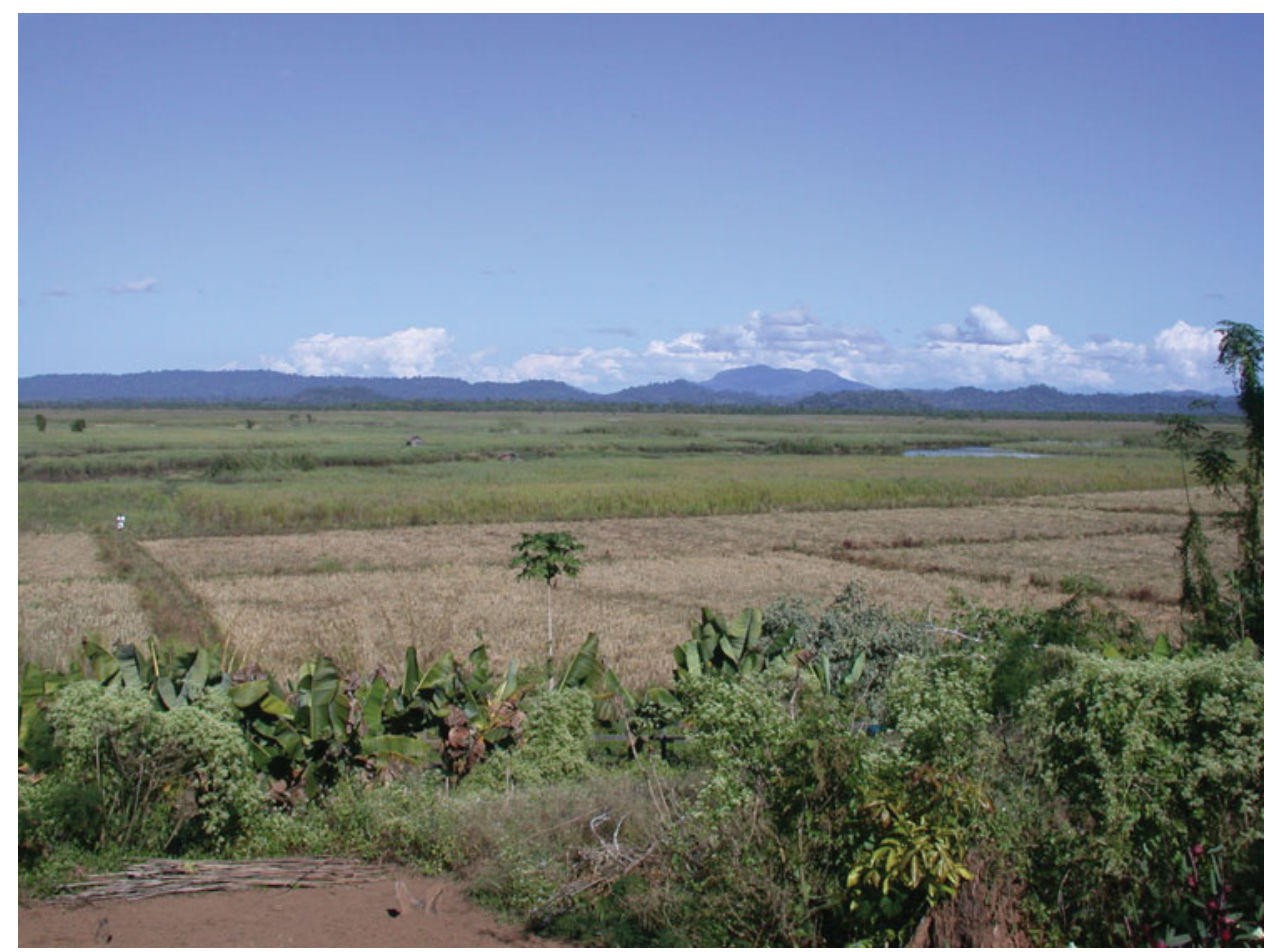

Figure 5. Nawng Kwin wetland, Kachin State. The photograph is taken from the point from where a possible sighting of Pink-headed Duck was made in December 2004. (Photograph by Andrew W. Tordoff.)

p. haringtoni, the most widespread subspecies of Spot-billed Duck in South-East Asia. It does not, however, rule out another subspecies, A. p. zonorhyncha, which has very reduced white in the tertials, and which was recorded in the lowlands of Kachin state during the NovemberDecember 2004 survey (Tordoff et al. in press).

The fact that the bill appeared to all three observers to be the same pale colour as the head and neck, as in an adult male Pink-headed Duck, rather than appearing dark with a contrasting pale tip, as in Spot-billed Duck (Figure 6), the facts that one observer (T.A.) thought that he saw pink on the head and neck as the bird initially flushed and that the flight of the bird was not obviously like that of any other duck, suggest that it was a Pink-headed Duck not a Spot-billed Duck. However, one observer (J.C.E.) noted white underwing coverts contrasting with dark flight feathers, which is a feature shown by Spot-billed Duck but not Pink-headed Duck, and none of the observers noted a pale leading edge to the upper wing coverts or contrasting (buff) secondaries, both of which are features of adult male Pink-headed Ducks.

While one of the observers (T.A.) felt that the bird seen at Nawng Kwin was very likely a Pink-headed Duck, the other two felt that it was not possible, on the basis of views obtained, to rule out the zonorhyncha subspecies of Spot-billed Duck. On balance, therefore, this record should be treated as a possible but unconfirmed sighting of Pink-headed Duck.

The place where Saw Aung thought that the bird had flushed from was visited on 2 December 2004. It comprised two pools of open water, each 10-12 $\mathrm{m}$ in diameter, in an area of knee-high, inundated grassland, c. $35 \mathrm{~m}$ wide, surrounded by taller grasses over $3 \mathrm{~m}$ in height. 


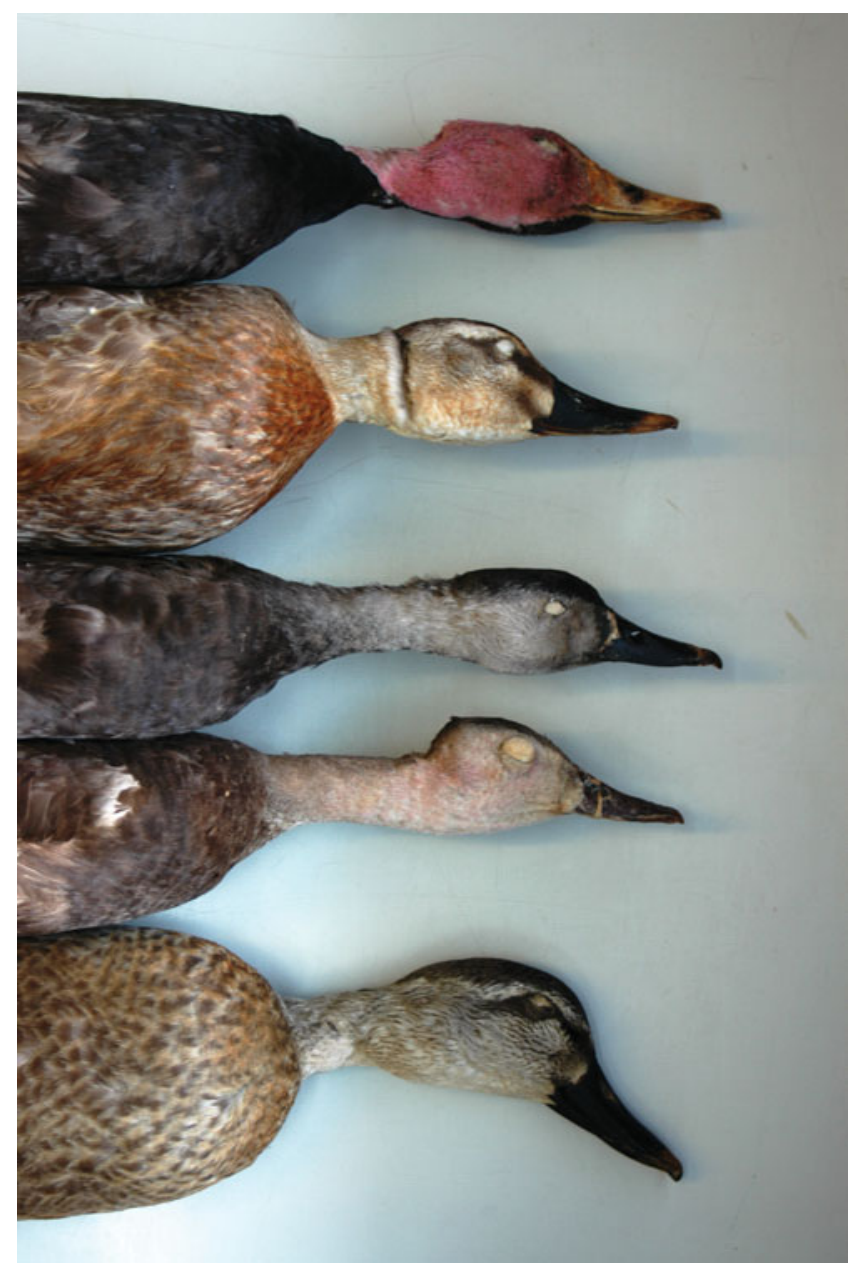

Figure 6. Comparison of heads of (from top to bottom): male Pink-headed Duck; male Spotbilled Duck subspecies zonorhyncha; female Pink-headed Duck; juvenile male Pink-headed Duck; Spot-billed Duck subspecies zonorhyncha. (Photograph by Jonathan C. Eames.)

\section{Kamaing}

On 8 December 2004, a boatman on the Tanai river reported to the survey team that he had seen a Pink-headed Duck in the Kamaing area, although without providing information on the date and year. The bird was reportedly seen alone out of the water.

A second anecdotal report related to the Kamaing area was received from Dr La Kha (the same person who reported having seen the species near Talawgyi; see above) on 1o October 2005. Dr La Kha reported seeing two ducks on the lower Indawgyi river, close to Kamaing town (Figure 2), in 1999 or 2000. The birds were reportedly swimming on the river and flushed when the boat he was travelling in approached. He reported noticing that the male had a pink, unusually shaped head but without a dark throat, as illustrated. He also reported that the female's head looked like a typical duck's. He added that the area where he saw the birds was a vast grassland at the time but had since been largely converted to cultivation. Considering that this report refers to birds 
swimming on a river and the equivocal description given, it seems more likely that these birds were Red-crested Pochards or, indeed, another duck species, than Pink-headed Duck.

The Kamaing area was visited briefly during December 2004, in response to second-hand reports of the occurrence of Pink-headed Duck and reports that the area supported pools in grassland. Unfortunately, the survey team was unable to procure a boat and the survey was restricted to anthropogenic habitats near Kamaing town $\left(25^{\circ} 31^{\prime} 3 \mathrm{O}^{\prime \prime} \mathrm{N}, 96^{\circ} 43^{\prime} \mathrm{oo}\right.$ 'E; c. $175 \mathrm{~m}$ a.s.l.; Figure 2).

A longer visit to the Kamaing area was made between 11 and 26 October 2005, during which the survey team visited 12 ox-bows and three large grasslands near the Nat Kaung river (Figure 2). The large grasslands visited contained a small number of scattered pools, and were drained by deep streams (Figure 7). During the visit, a number of anecdotal reports of Pink-headed Duck were received, several of which appeared to have been prompted by the posters circulated prior to the survey. On 13 October 2005, the survey team received a report from a man who claimed to have seen the bird on Nawng Kooh In $\left(25^{\circ} 41^{\prime} 15^{\prime \prime} \mathrm{N}, 96^{\circ} 39^{\prime} \mathrm{oo}\right.$ "E), a small ox-bow, c. 300 m west of the Nat Kaung river. He reported that the bird is very shy and always sees people before they see it, then retreats into emergent vegetation. The survey team visited Nawng Kooh In on the same day but it was very quiet with few birds.

On 13 October, the survey team received a report from a man who claimed to have seen two Pink-headed Ducks at night several months previously on Man Tin In $\left(25^{\circ} 29^{\prime} 15^{\prime \prime} \mathrm{N}, 96^{\circ} 45^{\prime} 45^{\prime \prime} \mathrm{E}\right)$, a large ox-bow, c. 600 m east of the Mogaung Chaung (Figure 2), downstream of Kamaing town. He described the male as dark with a pink head. He reported that the bird is very shy and keeps to the water's edge. The survey team visited Man Tin In on 27 October, and it appeared to be very suitable for waterfowl, with pools of open water amid floating vegetation and grasses. Only five Cotton Pygmy-geese Nettapus coromandelianus were seen, however.

On 16 October, the survey team received a report from Poh Sa, a farmer along the Nat Kaung river, who reported that, in September-October 2004, while looking for rubies near Za Baw

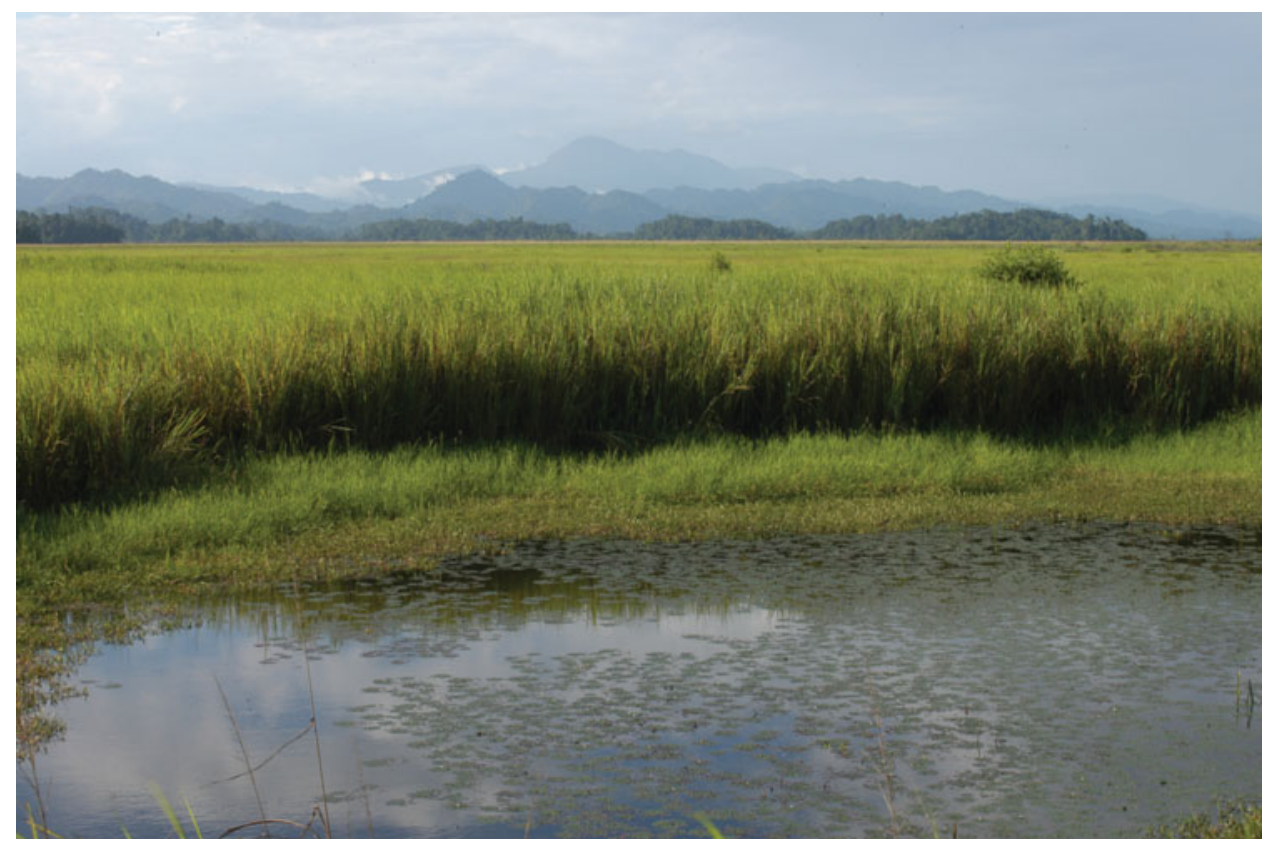

Figure 7. Kamaing area, Kachin State. The photograph shows one of the large grasslands studded with pools near the Nat Kaung river. (Photograph by Jonathan C. Eames.) 
village, he camped near a pool in a valley lined with wild bananas. Every evening, he reported, two ducks came to roost near his camp, leaving again every morning. He thought that the ducks were Pink-headed Ducks, because the male was larger and more colourful, while the female was smaller and paler. In response to this report, members of the survey team visited the pool near $\mathrm{Za}$ Baw village together with Poh Sa on 20 and 21 October, where they heard a White-winged Duck Cairina scutulata coming to roost in the evening and saw one leave on the following morning. This was one of several examples of local people having difficulty distinguishing between Pink-headed Duck and White-winged Duck. This problem was perhaps compounded by the fact that White-winged Duck was not included on the posters as a possible confusion species, and the fact that the illustration of the female Pink-headed Duck (which was taken from Grimmett et al. 1998) does superficially resemble a White-winged Duck.

On 17 October, the survey team received a report from a fisherman who claimed to have seen five Pink-headed Ducks on a pool in the large grassland to the north-east of the Nat Kaung river in 2004. He added that the ducks had been too shy to hunt. The survey team followed up this report on 19 October, and visited two medium-sized ox-bows by elephant back. The first ox-bow was over $100 \mathrm{~m}$ long, about $\mathrm{I} \mathrm{m}$ deep and bordered by tall grass and reeds. The second was about $200 \mathrm{~m}$ long and $20 \mathrm{~m}$ wide, with a row of stunted, submerged trees down the middle. Both oxbows were bordered on one side by forest and on the other by a large grassland, and neither showed any signs of human disturbance. However, no waterfowl were observed.

On 22 October, the survey team received several reports of an unusual duck from people living near the large grassland to the south-west of the Nat Kaung river. They reported that the bird visits pools in the grassland from the Thadingyut Festival (mid-October) onwards, that it keeps to itself and that it is never found together with other ducks. However, they described the bird as resembling domestic Muscovy Ducks Cairina moschata, which are widely kept in the area. Based on this description, these reports probably refer to White-winged Duck.

On 28 October, the survey team met with the leader of Shaduzup village in the south-east of Hukaung Tiger Reserve, who claimed that he had recently seen an unusual duck while hunting in the Kamaing area, which he thought might be Pink-headed Duck. After detailed enquiries, however, it transpired that the bird he had seen resembled a domestic Muscovy Duck. Consequently, this report probably also refers to White-winged Duck.

In addition to the various anecdotal reports received, one of the survey team (S.M.A.) had a possible but unconfirmed sighting of a Pink-headed Duck on Kyaw In $\left(25^{\circ} 39^{\prime} 15^{\prime \prime} \mathrm{N}, 96^{\circ} 41^{\prime} 15^{\prime \prime} \mathrm{E}\right)$. At around 17 h3o on 16 October, S.M.A. had a very brief ( $1-2$ second) view of a duck with a whitish, unusually shaped head, contrasting with a sandy brown body with a white patch in the folded wing. S.M.A. felt that the bird was probably a Pink-headed Duck but that he was not certain. His description would seem to fit only an immature bird, and should be treated as a possible but unconfirmed record. Kyaw In is a narrow ox-bow, c. $600 \mathrm{~m}$ in length, which lies $c$. $750 \mathrm{~m}$ east of the Nat Kaung river. The western shore of the ox-bow was bordered by gallery forest, while the eastern shore was bordered by a large grassland. The ox-bow contained a large amount of emergent vegetation, including small trees, as well as floating vegetation plus patches of open water. Survey team members revisited Kyaw In on the two following days, from before dawn until after dusk, with three observers watching from concealed positions spaced along the ox-bow on each day. However, only one further observation of a duck was made: a single Lesser Whistling Duck Dendrogyna javanica.

\section{Availability of habitat}

The BirdLife/BANCA surveys revealed that apparently suitable habitats for Pink-headed Duck remain in the lowlands of Kachin state. These habitats, which comprise grasslands with scattered pools, and ox-bow lakes in the floodplains of lowland rivers, are superficially similar to those described for the species in India. Hume and Marshall (1879-1881), for example, describe the species' habitat as "tanks and pools, thickly set with reeds and aquatic plants, swamps dense with 
beds of bulrushes and the like, and nullahs and ponds hemmed in by forest". Simson (1884) gives a similar description: "vast, extensive and much-neglected plains, studded at considerable intervals with small poor villages, intersected with very deep clear streams", terrain that was "difficult to cross on foot in the dry season", and home to "scattered ... pools of deep water, extending over areas from ten to forty acres, abounding in wild fowl and crocodiles, surrounded by very high grass ... and covered with beautiful lotus plants". On these pools, Simson (1884) reported, "the Pink-headed Duck resorts at all seasons of the year".

Similar habitats, albeit less extensive than those described by Simson (1884), persist in at least four sites in the lowlands of Kachin state: along the Tanai river; Nawng Kwin; the Kamaing area; and the Indawgyi river. The last site $\left(25^{\circ} \mathrm{Ig}^{\prime} \mathrm{OO} \prime \mathrm{N}, 96^{\circ} 3 \mathrm{I}^{\prime} \mathrm{OO}\right.$ " $\left.\mathrm{E}\right)$ appears, from remote sensing data, to include a significant area of grassland and swamp, scattered with pools. Due to permission difficulties, it was not possible to visit this area during the BirdLife/BANCA surveys. The former three sites were surveyed extensively, with possible sightings of Pink-headed Duck being made at two of them and detailed anecdotal reports of the occurrence of the species being received at all three of them.

\section{Current status of Pink-headed Duck in Myanmar}

Possible sightings and anecdotal reports aside, the fact that three sites were found to support apparently suitable habitat for Pink-headed Duck raises the question of why the species was not confirmed there, despite intensive survey effort. One hypothesis is that the species never occurred at these sites, a second is that is occurred there historically but has since become extirpated, while a third is that there are features of the species' ecology which led to it being overlooked during the surveys.

Evidence in favour of the first hypothesis includes: (i) there are no historical records from any of these sites; and (ii) available information on the ecology and habitat requirements of Pinkheaded Duck (in particular, the almost total lack of data pertaining to the species' habitat requirements in Myanmar) are not sufficiently detailed to permit an accurate assessment of whether any extant habitats are suitable for the species. Evidence against the first hypothesis includes: (i) there are two historical reports of Pink-headed Duck from the lowlands of Kachin state; and (ii) the lowlands of Kachin state were the focus of very limited ornithological study historically. If there are features of the species' ecology that meant that it tended to be underrecorded, the scarcity of historical records from this little-studied area is unsurprising.

The principal evidence in favour of the second hypothesis is that all three sites displayed signs of human disturbance, including fishing, conversion of grassland to cultivation and burning of grassland, while, in the case of the Tanai river, hunting of waterbirds was observed. Indeed, several informants claimed to have considered, attempted to or succeeded in hunting the species in recent years. Evidence against the second hypothesis includes: (i) all three sites were found to support one or more waterbird species that are sensitive to human disturbance and/or hunting pressure and, consequently, have undergone extensive declines in South and South-East Asia over the last century, including White-winged Duck, Masked Finfoot Heliopais personata and Black-necked Stork Ephippiorhynchus asiaticus, and it seems improbable that disturbance and/or hunting pressure would have led to the eradication of Pink-headed Duck but not these species; (ii) anecdotal reports of the continued presence of the species were received from all three sites, and while some of these reports appeared, on closer questioning, to refer to White-winged Duck, others were consistent with Pink-headed Duck; and (iii) possible but unconfirmed sightings were made at two of the sites.

Evidence in favour of the third hypothesis includes: (i) there are several historical reports that the bird is shy and wary of humans: Irby (1861) called it "excessively wary", while Jerdon (1862-1864) called it "shy and somewhat wary"; (ii) a number of informants interviewed during the BirdLife/BANCA surveys corroborated these historical reports, by describing the bird as "very shy" and that it "always sees people before they see it, then retreats into emergent 
vegetation"; (iii) there is a significant amount of historical evidence that the bird seldom flies during the middle of the day; Jerdon (1862-1864), for instance, reported that "during the heat of the day, it generally remains near the middle of the tank or jheel"; in this context it is notable that the survey of Nawng Kwin and the two surveys along the Tanai river were impeded by dense fog, which typically did not lift until mid-morning, after the end of the peak period for bird activity; (iv) there is historical evidence that the species may feed at night, like many other duck species: Simson (1884) reported that the species was "seldom ... seen flying to the feedingground before sunset, but stays all day in the pools, where it lives till disturbed", while B. H. Hodgson (in Hume and Marshall 1879-1881) reported that it "feeds at night"; and (v) historical evidence that the species may be at least partly nocturnal is corroborated by two informants interviewed during the BirdLife/BANCA surveys, who reported seeing (and, in one case, hunting) it at night.

On balance, therefore, there are several reasons for believing that Pink-headed Duck may still persist in the lowlands of Kachin state and, perhaps, elsewhere in Myanmar. Shyness, combined with rarity, possible nocturnal habits and the impenetrability of its habitats, means that the species tended to be under-recorded historically, and may continue to be so currently. This set of factors would explain why several historical records of the species related to incidental sightings (or shooting) of birds flushed by hunting parties penetrating inhospitable grassland terrain in search of tiger (e.g. Baker 1922-1930).

\section{Recommendations}

\section{Site conservation and safeguard}

Regardless of whether or not they support Pink-headed Duck, the Tanai river, Nawng Kwin and the Kamaing area are all priorities for conservation action. These three sites support wetland and (in the case of the latter two) grassland bird communities that are as close to an original (pre1900) state, in terms of species composition and abundance, as any in mainland South-East Asia, and support some of the best remaining examples of wetland and grassland ecosystems remaining in the region. Only the Tanai river is currently included within an established protected area (Hukaung Tiger Reserve). Both the Nawng Kwin wetland and key habitats within the Kamaing area should be placed under conservation management, whether formal protected area status or non-formal management by local stakeholders. In addition, all three sites should be integrated into land-use and development plans, to safeguard against the risk of their integrity being compromised by incompatible land-use or infrastructure development planning decisions.

\section{Further research}

The review of historical and recent information on the status of Pink-headed Duck in Myanmar presented in this paper reveals that the species may possibly persist in lowland wetlands in Kachin state, although this has not been confirmed. Consequently, there is a need for further surveys of lowland wetlands in Kachin state, to determine whether they support the species, and, if the species is confirmed to occur, to assess its status, distribution and habitat requirements. Priority sites for further studies include the Tanai river, Nawng Kwin, the Kamaing area and the area of grassland and swamp along the Indawgyi River north-east of Indawgyi lake. At each of these sites, analysis of remote sensing data should be undertaken to determine the extent of remaining grassland habitat, and the location of pools and ox-bows, followed by field surveys in multiple seasons. Given the possibility that the species is at least partly nocturnal, particular attention should be paid to finding vantage points overlooking apparently suitable pools and oxbows, and mounting all-night vigils. 
Further surveys are also required of wetland areas away from the lowlands of Kachin state, following a similar approach. In particular, the Singu-Mandalay area may be worthy of attention, as it is from this general area that the two historical specimens are thought to have originated. The stretch of the Ayeyarwady river between Singu and Mandalay towns (c. $60 \mathrm{~km}$, in a straight line) is extensively braided and its floodplain contains a large number of pools and small lakes. While this area appears, from remote sensing data, to contain a significant amount of human settlement and cultivation, field surveys may reveal remote, seldom visited wetlands, which could potentially be suitable for the species. One site worthy of a follow-up visit focusing on Pink-headed Duck is Khu Le In, Singu township, Mandalay division, which may correspond to "Koolay near Singu", an historical collecting locality for the species. Khu Le In was visited on II February 2001 by a team from the Wild Bird Society of Japan and the Nature and Wildlife Conservation Division of the Myanmar Forest Department (Davies et al. 2004). However, the team appear not to have been aware of the site's significance as a possible collecting locality for Pink-headed Duck, nor to have made any specific investigation about the species.

Away from the Singu-Mandalay area, a detailed analysis of wetland habitats in Rakhine state should be conducted, in light of the provisional historical record from there. If potentially suitable habitat is identified, field surveys should be undertaken, adopting a similar approach to that outlined above.

\section{Acknowledgements}

The preparation of this paper and the fieldwork reported herein were generously supported by the Darwin Initiative, as part of the project entitled Building Constituencies for Site-based Conservation in Myanmar, and the BirdLife International Asia Bird Fund. The authors would like to thank the Ministry of Travel and Tours in Myanmar for granting permission for fieldwork. The authors also wish to thank Robert Prys-Jones of The Natural History Museum (Tring) and Clem Fisher of World Museum Liverpool for permission to view skins of Pinkheaded Duck, as well as Paul Sweet and Shannon Kenney of AMNH and Asad Rahmani and Zafar-ul Islam of BNHS for their assistance in obtaining photographs of Pink-headed Duck specimens in their collections.

\section{References}

Ali, S. (1960) The Pink-headed Duck Rhodonessa caryophyllacea (Latham). Wildfowl Trust 11th Annual Report: 55-60.

Baker, E. C. S. (1922-1930) The fauna of British India, including Ceylon and Burma. Second edition. London: Taylor and Francis.

BirdLife International (2001) Threatened birds of Asia: the BirdLife International Red Data Book. Cambridge, U.K.: BirdLife International.

BirdLife International (2003) Saving Asia's threatened birds: a guide for government and civil society. Cambridge, U.K: BirdLife International.
Blyth, E. (1875) Catalogue of mammals and birds in Burma. J. Asiatic Soc. Bengal 44(2): extra number.

Bucknill, J. A. (1924) The disappearance of the Pink-headed Duck. Ibis 11 (6): 146-151.

Christison, P., Buxton, A., Emmer, A. M. and Ripley, D. (1946) Field notes on the birds of coastal Arakan and the foothills of the Yomas. J. Bombay Nat. Hist. Soc. 46: 13-32.

Davies, J., Sebastian, A. C. and Chan, S., eds. (2004) A wetland inventory for Myanmar. Tokyo: Ministry of Environment, Japan.

Grimmett, R., Inskipp, C. and Inskipp, T. (1998) Birds of the Indian Subcontinent. London: Christopher Helm. 
Harington, H. H. (1909) The birds of Burma. Rangoon: Rangoon Gazette Press.

Harington, H. H. (1909-1910) A list of the birds of the Bhamo district of Upper Burma. J. Bombay Nat. Hist. Soc. 19: 107-128, 299-313.

Hume, A. O. and Marshall, C. H. T. (18791881) The game birds of India, Burmah and Ceylon. Calcutta: published by the authors.

Irby, L. H. (1861) Notes on birds observed in Oudh and Kumaon. 1615 3: 217-251.

IUCN (2006) 2006 IUCN Red List of threatened species. Downloaded from www.redlist.org on 14 May 2006.

Jardine, E. R. (1909) Occurrence of the Pinkheaded Duck (Rhodonessa caryophyllacea) in Burma. J. Bombay Nat. Hist. Soc. 19: 264.

Jerdon, T. C. (1862-1864) The birds of India. Calcutta: privately published.

Kear, J. and Williams, G. (1978) Waterfowl at risk. Wildfowl 29: 5-21.

Oates, E. W. (1883) A handbook to the birds of British Burmah, including those found in the adjoining state of Karennee. Volumes 1-2. London: R. H. Porter and Dulau \& Co.
Oates, E. W. and Blandford, W. T. (18891898) The fauna of British India including Ceylon and Burma. Birds. Volumes. 1-4. London: Taylor and Francis.

Simson, F. B. (1884) Notes on the Pinkheaded Duck (Anas caryophyllacea). Ibis 5(2): $271-275$.

Singh, L. P. (1967) The Pinkheaded Duck again. J. Bombay Nat. Hist. Soc. 63: 440.

Smythies, B. E. (1986) The birds of Burma. Third edition. Liss, U.K.: Nimrod Press, and Pickering, Ontario: Silvio Mattachione and Co.

Tordoff, A. W., Appleton, T., Eames, J. C., Eberhardt, K., Htin Hla, Khin Ma Ma Thwin, Sao Myo Zaw, Saw Moses and Sein Myo Aung (in press) Avifaunal surveys in the lowlands of Kachin State, Myanmar, 2003-2005.

van der Ven, J. (2000) Myanmar expedition 1999-2000. Unpublished report.

van der Ven, J. (2001) Myanmar expedition 2000-2001. Unpublished report.

van der Ven, J. (2002) Myanmar expedition 2001. Unpublished report.

van der Ven, J. (2003) Myanmar expedition 2003. Unpublished report.

ANDREW W. TORDOFF*

BirdLife International Wellbrook Court, Girton Road, Cambridge CB3 oNA, UK.

TIM APPLETON

Rutland Water Nature Reserve, Egleton, Oakham, Rutland, LE15 8BT, U.K.

JONATHAN C. EAMES

BirdLife International in Indochina, N6/2+3, Lane 25, Langtla Street, Hanoi, Vietnam.

KARIN EBERHARDT

8oP Kanbawza Lane 1, Bahan Township, Yangon, Myanmar.

HTIN HLA, KHIN MA MA THWIN

Biodiversity and Nature Conservation Association, A/6-2 Anawrathar Housing, Hledan, Ward \#2, Kamayut Township, Yangon, Myanmar.

SAO MYO ZAW, SAW MOSES, SEIN MYO AUNG

Wildbird Adventure Travels and Tours, P. O. Box 1136, Yangon, Myanmar.

*Author for correspondence; e-mail: jackbirdlife@hotmail.com

Received 27 June 2006; revision accepted 26 April 2007 